Original Research Article

\title{
Age and gender based prevalence of obesity in residents of Punjab, India
}

\author{
Satinderjit Singh ${ }^{1}$, Ravjit Kaur Sabharwal ${ }^{2 *}$ Jagminder Kaur Bajaj $^{3}$, \\ Indira R. Samal'2, Megha Sood ${ }^{3}$
}

${ }^{1}$ Department of Surgery, Civil Hospital, Jalandhar, Punjab, India

${ }^{2}$ Department of Biochemistry, ${ }^{3}$ Department of Pharmacology, Punjab Institute of Medical Sciences, Jalandhar, Punjab, India

Received: 02 March 2019

Revised: 19 March 2019

Accepted: 03 April 2019

*Correspondence to:

Dr. Ravjit Kaur Sabharwal, Email: ravjit.sabharwal@ gmail.com

Copyright: (C) the author(s), publisher and licensee Medip Academy. This is an openaccess article distributed under the terms of the Creative Commons Attribution NonCommercial License, which permits unrestricted noncommercial use, distribution, and reproduction in any medium, provided the original work is properly cited.

\begin{abstract}
Background: Obesity is recognized as a chronic disease, associated with a variety of metabolic, cardiovascular and neurological complications. Prevalence of obesity is increasing worldwide, more so in the developing countries. It is affecting both sexes and all age groups. Body mass index BMI along with presence and severity of obesity associated complications are used to identify, successively increasing stages of obesity. The present study aims to study prevalence of overweight, obesity (stage $0,1,2$ ) and morbid obesity in adult residents of Punjab state in an effort to determine burden of this lifestyle disorder in different age groups and sexes, so that a comprehensive action plan can be designed to target appropriate group with specific preventive measures .

Methods: 1000 subjects were surveyed and labelled as non-obese, overweight, obese or morbid obese based on their BMI, presence and severity of obesity related complications. Point prevalence amongst different age groups of both sexes were determined and compared.

Results: In study population $41.5 \%$ subjects were non-obese, $15.9 \%$ were overweight, $29.4 \%$ were obese and $13.2 \%$ were morbidly obese. The prevalence of all the 3 conditions (overweight, obesity and morbid obesity) increased with increasing age in both sexes. The prevalence was more among females of all age groups than males for 'overweight' and 'obesity'. But gender based difference narrowed down with increasing severity of disease, such that female to male ratio reversed (<1) for morbid obesity. Moreover, peak prevalence of overweight and obesity were attained little later in females as compared to males. However, for morbid obesity peak prevalence is seen in same age group (40-49 years) in both sexes.

Conclusions: Overweight and obesity are more prevalent among females of all age groups than males with peak prevalence achieved little later in females as compared to males. However, gender based differences in prevalence decreased as severity increased and morbid obesity was more prevalent among males than females.
\end{abstract}

Keywords: Body mass index, Complications, Morbid obesity, Overweight, Peak prevalence, Punjabi population

\section{INTRODUCTION}

Obesity is a lifestyle disorder prevalent worldwide. It is defined as "a condition of increased percentage body fat to an extent that impairs health and well being". WHO has declared the alarming increase in prevalence of obesity as "global epidemic" and acknowledged its status as a 'disease' in the year 2000. ${ }^{1}$ It is being increasingly recognized as a 'chronic disease' associated with large number of complications like diabetes mellitus, hypertension, stroke, osteoarthritis, gall stones, sleep apnoea and even some malignant diseases, which can 
reduce life span..$^{2-6}$ The prevalence of obesity is increasing throughout the world, affecting both sexes and all age groups. The rate of rise of prevalence is reportedly higher in developing countries than in developed ones. ${ }^{7}$ In India, obesity has acquired epidemic proportions with $5 \%$ of country`s population being obese and the prevalence is further rising rapidly, especially in adult population. ${ }^{8,9}$

In a large majority (approximately 95\%) of cases, obesity results from 'energy imbalance' due to surplus intake of energy dense diet, coupled with sedentary life style. In rest of the cases it is secondary to drugs or diseases (metabolic, endocrine and genetic). ${ }^{10}$ Punjab is one of the affluent states of India with people traditionally having habit of indulging in energy rich food. This factor along with increasing urbanization, stress, sedentary life style, availability and affordability of junk / energy dense food presumably places this population at a greater risk of developing obesity.

The most frequently used parameter to label someone as overweight or having varying grades of obesity is 'Body mass index' (BMI). It is the ratio of person's weight in kilograms to square of his height in meters. Its unit is thus kilogram per square meter $\left(\mathrm{kg} \mathrm{m}^{-2}\right)$. BMI of 18-24.9 is labelled as normal, $\geq 25-29.9$ overweight and 30- 39.9 as obese (stage 0) if there are no weight related complications. However, in the presence of complications $\mathrm{BMI} \geq 25-34.9$ can be obesity stage 1 or stage 2 depending on severity of complication being mild to moderate or severe respectively. ${ }^{11}$

\section{Table 1: Obesity criteria. ${ }^{11}$}

\begin{tabular}{|ll|}
\hline Criterion & Obesity stage \\
\hline BMI 18-24.9, no complications & Normal weight \\
\hline BMI $\geq 25-29.9$, no complications & Over weight \\
\hline BMI $\geq 30$, no complications & Obesity stage 0 \\
\hline $\begin{array}{l}\text { BMI } \geq 25, \text { mild to moderate } \\
\text { complications }\end{array}$ & Obesity stage 1 \\
\hline BMI $\geq 25$, severe complications & Obesity stage 2 \\
\hline
\end{tabular}

BMI of $\geq 35$ with obesity related health conditions or $\geq 40$ even in absence of complications is labelled as morbid obesity. ${ }^{12-14}$ Thus presence and severity of associated complications are important criteria in addition to BMI to help identity successively increasing stages of obesity and risk to health.

Obesity, being a life style related disease can be controlled by taking preventive measures. The classification of population into normal weight, overweight, obese and morbidly obese can help to make a 'comprehensive action plan' to target appropriate group with specific preventive measures.

Normal weight population needs primary preventive interventions such as health education about proper diet, exercise and lifestyle modification to prevent obesity.
People who have BMI more than the normal range but have not yet developed obesity related complications require secondary measures to control progressive weight gain and prevent development of complications. However, more aggressive tertiary interventions should be directed towards persons having higher grades of obesity, since they are already experiencing the ill effects of increased body weight. Tertiary interventions aim at treating and preventing further worsening of the complications. In a country like India with ever expanding population load and inadequate health care services, obesity control measures can be put into optimum use if population groups at higher risk of developing obesity are recognized. They should be designated as being appropriate for primary, secondary or tertiary preventive interventions. This will optimize the patient outcomes as well as improve the cost effectiveness and benefit-risk ratio of intervention. ${ }^{15,16}$

Hence, this study was planned with an aim of determining the prevalence of overweight, obesity and morbid obesity, its distribution across both sexes and different age groups in residents of Punjab.

\section{Objectives}

- $\quad$ Prevalence of overweight, obesity (stages $0,1,2$ ) and morbid obesity

- $\quad$ Age wise distribution of overweight, obesity (stages $0,1,2$ ) and morbid obesity

- Gender wise distribution of overweight, obesity (stages 0,1,2) and morbid obesity amongst the residents of Punjab.

\section{METHODS}

It was hospital based, cross sectional, observational study.

\section{Study population}

Adult patients who reported in the 'sample collection center' from various out patient departments (OPDs) of Punjab Institute of Medical Sciences, Jalandhar were included in the study. Highly muscular, oedematous, very old, sarcopenic and pregnant patients were excluded from the study.

\section{Procedure}

After obtaining permission from the IEC and informed written consent, the study was conducted on 1000 adult patients. Patient's name, age, sex, religion, marital, educational and economic status were recorded on a selfstructured, prevalidated proforma. Detailed dietary habits and routine of physical activity were noted down. History of obesity related complications like diabetes mellitus, hypertension, gall stones, stress incontinence, snoring and weight pattern over previous few years were recorded. On physical examination weight in kilograms and height in meters was recorded and BMI was calculated by using the given formula. 
$\mathrm{BMI}=$ weight $(\mathrm{Kg}) /$ Height $(\mathrm{m})^{2}$

Unit - $\mathrm{kgm}^{-2}$

General physical and systemic examination of cardiovascular, respiratory system, abdomen and joints was done to determine presence of any obesity related complications. Necessary investigations like Fasting Blood Sugar (FBS), Lipid Profile, Liver Function Test (LFT), Renal Function Test (RFT) and HbAIC were done as required in individual patients. Data were recorded in MS Excel and analyzed to see percentage prevalence of overweight, obesity and morbid obesity in males and females of different age groups viz $<30$ years, 30-39 years, $40-49$ years and $>50$ years old.

\section{RESULTS}

A total of 978 patient's data were tabulated and analysed. 22 proformas with incomplete information were excluded from the study. Table 2 shows study population to be heterogenous. The age ranged from 18-77 years.

Table 2: Age and sex distribution of study population.

\begin{tabular}{|llll|}
\hline Age group & $\begin{array}{l}\text { Total } \\
\text { number }\end{array}$ & Males (n) & Females (n) \\
\hline$<30$ years & 297 & 123 & 174 \\
\hline 30-39 years & 212 & 74 & 138 \\
\hline 40-49 years & 179 & 63 & 116 \\
\hline$\geq 50$ years & 290 & 129 & 161 \\
\hline Total & 978 & $389(39.8 \%)$ & $589(60.2 \%)$ \\
\hline
\end{tabular}

In this study, $60.2 \%$ of study subjects were females and the rest were males. Since study subjects were selected randomly, number of females was more than males (589 females in comparison to 389 males). Thus, the results are given as percentages for better comparison.

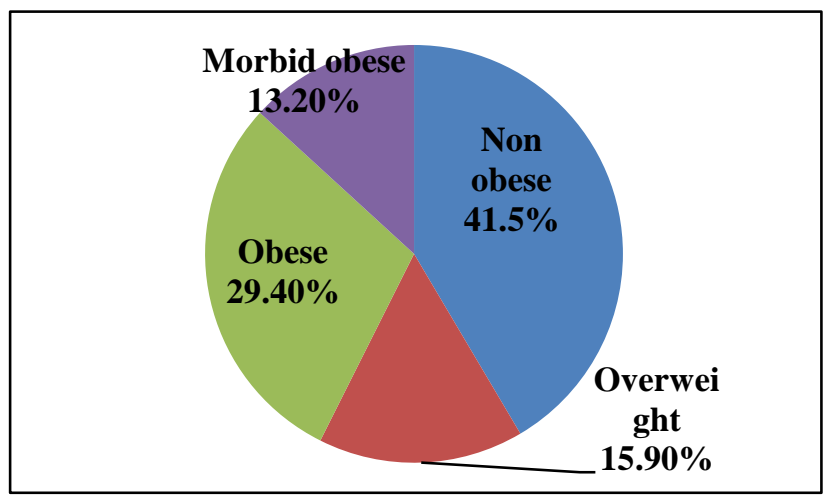

Figure 1: Overall prevalence of overweight, obesity and morbid obesity in study population.

As shown in Figure 1 out of a total of 978 subjects, less than half $(41.5 \%$ only) had BMI in normal or non-obese range. $15.9 \%$ were overweight. The overall prevalence of obesity was found to be alarmingly high $(29.4 \%)$ in the study population. The prevalence of more severe form of obesity called 'morbid obesity' was also high (13.2\%).

The Point prevalence of 'overweight' and 'morbid obesity' was maximum in age group of 40-49 years and that of 'obesity' in 50 years or older subjects in the study population (Table 3 ).

The gender wise point prevalence of overweight and obesity is higher in females than males. However, 'morbid obesity is observed to be slightly more prevalent among males as shown in Table 4. Female to male prevalence ratio decreases as the severity increases and becomes <1 for morbid obesity $(0.92: 1)$.

Table 3: Overall Point prevalence of overweight, obesity and morbid obesity in different age groups.

\begin{tabular}{|llllllllll|}
\hline Age group & $\begin{array}{l}\text { Total ' } n \text { ' in } \\
\text { study group }\end{array}$ & \multicolumn{2}{l}{$\begin{array}{l}\text { Non obese } \\
\text { No: Percent }\end{array}$} & \multicolumn{2}{l}{$\begin{array}{l}\text { Overweight } \\
\text { No: Percent }\end{array}$} & \multicolumn{2}{l|}{$\begin{array}{l}\text { Obese } \\
\text { No: Percent }\end{array}$} & \multicolumn{3}{l|}{$\begin{array}{l}\text { Morbid obese } \\
\text { No: Percent }\end{array}$} \\
\hline$<30$ & 297 & 187 & 62.9 & 43 & 14.5 & 51 & 17.2 & 16 & 5.4 \\
\hline $30-39$ & 212 & 83 & 39.1 & 42 & 19.8 & 61 & 28.8 & 26 & 12.3 \\
\hline $40-49$ & 179 & 46 & 25.7 & 36 & 20.1 & 63 & 35.2 & 34 & 18.9 \\
\hline$\geq 50$ & 290 & 90 & 31.0 & 34 & 11.7 & 113 & 39 & 53 & 18.3 \\
\hline Total $n$ and \% & 978 & 406 & $41.5 \%$ & 155 & $15.9 \%$ & 288 & $29.4 \%$ & 129 & $13.2 \%$ \\
\hline
\end{tabular}

Table 4: Gender wise point prevalence.

\begin{tabular}{|llllll|}
\hline Severity stage & $\begin{array}{l}\text { Males }(\mathbf{n = 3 8 9}) \\
\text { No: percent }\end{array}$ & $\begin{array}{l}\text { Females }(\mathbf{n = 5 8 9}) \\
\text { No: percent }\end{array}$ & $\begin{array}{l}\text { Female to male } \\
\text { prevalence ratio }\end{array}$ \\
\hline Non -obese & 189 & 48.5 & 217 & 36.9 & $1.38: 1$ \\
\hline overweight & 50 & 12.9 & 105 & 32.6 & $1.32: 1$ \\
\hline Obese & 96 & 24.7 & 192 & 12.7 & $0.92: 1$ \\
\hline Morbid obese & 54 & 13.9 & 75 & & \\
\hline Total & 389 & & 589 & & \\
\hline
\end{tabular}


The prevalence amongst males increases as the age advances and the peak prevalence of both obesity and morbid obesity is observed in the age groups of 40-49 years, whereas that for overweight in 30-39 years.

Table 5: Age-wise prevalence in males.

\begin{tabular}{|lllll|}
\hline $\begin{array}{l}\text { Age } \\
\text { groups }\end{array}$ & $\begin{array}{l}\text { Total } \\
\text { number }\end{array}$ & $\begin{array}{l}\text { Overweight } \\
\mathbf{N}(\%)\end{array}$ & $\begin{array}{l}\text { Obesity } \\
\mathbf{N}(\%)\end{array}$ & $\begin{array}{l}\text { Morbid } \\
\text { obesity } \\
\mathbf{N}(\%)\end{array}$ \\
\hline $\begin{array}{l}<30 \\
\text { years }\end{array}$ & 123 & $16(13 \%)$ & $\begin{array}{l}17 \\
(13.8 \%)\end{array}$ & $\begin{array}{l}10 \\
(8.1 \%)\end{array}$ \\
\hline $\begin{array}{l}30-39 \\
\text { years }\end{array}$ & 74 & $12(16.2 \%)$ & $\begin{array}{l}18 \\
(24.3 \%)\end{array}$ & $\begin{array}{l}8 \\
(10.8 \%)\end{array}$ \\
\hline $\begin{array}{l}40-49 \\
\text { years }\end{array}$ & 63 & $8(12.7 \%)$ & $\begin{array}{l}21 \\
(33.3 \%)\end{array}$ & $\begin{array}{l}12 \\
(19.04 \%)\end{array}$ \\
\hline $\begin{array}{l}50 \\
\text { years }\end{array}$ & 129 & $14(10.9 \%)$ & $\begin{array}{l}40 \\
(31 \%)\end{array}$ & $\begin{array}{l}24 \\
(18.6 \%)\end{array}$ \\
\hline
\end{tabular}

Analysis of age wise prevalence in females also indicates similar trend of increasing prevalence with increasing age, with some differences (Table6). Peak prevalence is observed little later among females as compared to males. 'Overweight' and 'morbid obesity' show highest prevalence in 40-49 years age group, whereas, obesity prevalence maximizes in females aged 50 years and above.

Table 6: Age-wise prevalence in females.

\begin{tabular}{|lllll|}
\hline $\begin{array}{l}\text { Age } \\
\text { groups }\end{array}$ & $\begin{array}{l}\text { Total } \\
\text { number }\end{array}$ & $\begin{array}{l}\text { Overweight } \\
\mathbf{N}(\%)\end{array}$ & $\begin{array}{l}\text { Obesity } \\
\mathbf{N}(\%)\end{array}$ & $\begin{array}{l}\text { Morbid } \\
\text { obesity } \\
\mathbf{N}(\%)\end{array}$ \\
\hline $\begin{array}{l}<30 \\
\text { years }\end{array}$ & 174 & $27(18.2 \%)$ & $\begin{array}{l}34 \\
(19.5 \%)\end{array}$ & $6(3.4 \%)$ \\
\hline $\begin{array}{l}30-39 \\
\text { years }\end{array}$ & 138 & $30(21.7 \%)$ & $\begin{array}{l}43 \\
(31.2 \%)\end{array}$ & $\begin{array}{l}18 \\
(13.04 \%)\end{array}$ \\
\hline $\begin{array}{l}40-49 \\
\text { years }\end{array}$ & 116 & $28(24.1 \%)$ & $\begin{array}{l}42 \\
(36.2 \%)\end{array}$ & $\begin{array}{l}22 \\
(18.9 \%)\end{array}$ \\
\hline $\begin{array}{l}50 \\
\text { years }\end{array}$ & 161 & $20(12.4 \%)$ & $\begin{array}{l}73 \\
(45.3 \%)\end{array}$ & $\begin{array}{l}29 \\
(18.01 \%)\end{array}$ \\
\hline
\end{tabular}

Thus, this study finds that both overweight and obesity are more prevalent among females than males with peak prevalence achieved earlier in males as compared to females as depicted in Table 5.

However, gender based difference decreases as severity increases, such that 'morbid obesity' becomes most prevalent amongst males aged 40-49 years Table 5.

\section{DISCUSSION}

Obesity is a disease of global concern. It is the forerunner of a multitude of metabolic, cardiovascular, psychiatric and even malignant diseases that impair the health, deteriorate the quality of life and reduce life span. Obesity is not only an important preventable cause of death but is also the most neglected one throughout the world. ${ }^{1,17}$ Thus surveillance programs for identifying population groups at higher risk of developing obesity and related complications can optimize the use of scarcely available health resources.

In the present study, body mass index (BMI) exceeded the normal range (18-24.9) in more than half (58.5\%) of Punjabi population. Deepa $\mathrm{M}$ et al, reported a prevalence of $45.9 \%$ in Chennai and Bhardwaj et al, reported the prevalence of generalized obesity to be 50.1 In North India. ${ }^{18,19}$ An upward trend in obesity prevalence over the years is obvious from comparison of these figures.

However, our results are not in agreement with those of Shirazi et al, where prevalence of obesity is reported to be only $7.05 \%$ in Kashmiri Population in 2014. ${ }^{20}$ Abbas et al, and Khan et al, had also reported approximately same prevalence $\left(7-8 \%\right.$ ) a decade earlier in $2003 .^{21,22}$

ICMR INDIAB study also reported a comparatively lower prevalence of $24.6 \%$ and $31.3 \%$ among residents of Tamil Nadu and Chandigarh respectively in $2015{ }^{23}$

This study found obesity prevalence to increase with advancing age in both sexes. Peak prevalence of obesity is seen at 40-49 years of age for males and at or after 50 years of age for females. Undavalli et al, also reported obesity prevalence to be higher in women and in individuals in the age group of 41-50 years in rural Andhra Pradesh in $2018 .^{24}$

The prevalence of overweight and obesity is observed to be more in females than males. Such gender based differences in obesity prevalence have been reported in many studies conducted in different regions of world. The national family health survey 3 reported obesity to be more prevalent in women than men in India. ${ }^{25}$ Pandey et al and Al Mahroos et al, also reported higher obesity prevalence among females, in all age groups. ${ }^{26,27}$ Serena et al, observed more females to be obese than males especially in the developing countries. ${ }^{28}$ In this study female to male prevalence ratio is $1.38: 1$ for overweight, 1.32:1 for obesity and 0.92:1 for morbid obesity. A study by Shirazi etal also found female to male obesity prevalence ratio to be $1.26: 1 .^{20}$ A study conducted by health ministry of Singapur in 1999 also reported similar findings. ${ }^{29}$

It is interesting to note that the prevalence of morbid obesity was more in males than females (ratio 0.92:1) with peak prevalence in 40-49 years age group for both sexes. A WHO data report published in 2017 observed prevalence of $\mathrm{BMI} \geq 30$ to be $5.1 \%$ in males and $2.7 \%$ in females. ${ }^{30}$ Charlton $\mathrm{W}$ et al, reported that in American Indians prevalence of class II (BMI 35- 39.9) and Class III obesity $(\mathrm{BMI} \geq 40)$ was higher in women than men from 1995 to 2004 and was increasing every year in both sexes. The Percentage prevalence increase was, however, significantly greater for men than women. Thus, in severe degree obesity the sex difference was narrowing every year. ${ }^{31}$ This finding is in congruence with our results where gender based difference in prevalence among women and 
men is decreasing with increasing severity and ratio reverses (becomes <1) for morbid obesity. In contrast to our findings, Odegan et al had concluded that women are disproportionately affected by extreme obesity than men, regardless of age, race or ethinicity. ${ }^{32}$

The strength of our study lies in using presence of obesity related complications for diagnosis in addition to BMI. However, the study is hospital based, cross sectional study and observations may not be generalized.

\section{ACKNOWLEDGEMENTS}

The authors express gratitude to all members of Pharmacology and Biochemistry Department for providing constant support during the conduct of study.

Funding: No funding sources

Conflict of interest: None declared

Ethical approval: The study was approved by the Institutional Ethics Committee

\section{REFERENCES}

1. Obesity: preventing and managing the global epidemic. Report of a WHO consultation. World health organization Pech Rep Sir. 2000;894:1x11:1253. Available at: www.iosrjournals.org/iosrjdms/pages/13(4)version-7.html

2. Javed A, Hassan H. Characteristics of diabetic patients. Ann King Edward Med J. 2000;6(2):196-9.

3. Kumar P, Clark M. Obesity In: Kumar P, Clark M, eds. Clinical Medicine. $4^{\text {th }}$ Ed. Philadelphia: WB Saunders; 1998:209.

4. Sood R, Gupta A. An epidemiological study of obesity in Shimla town. Indian J Med Sci. 1996 Oct;50(10):362-4.

5. Stevens J. Impact of age on association between weight and mortality. Nutr Rev. 2000 May;58(5):12937.

6. Bray GA, Bellanger T. Epidemiology, trends and morbidities of obesity and the metabolic syndrome. Endocrine. 2006;29:109-17.

7. Chopra M, Galbraith S, Darnton-hill I. A global response to a global problem: the epidemic of over nutrition. Bull World health Organ. 2002;80:952-8.

8. The Hindu. India facing obesity epidemic: experts, 2007. Available

at: http://hindu.com./2007/10/12/stories/2007101260940 600.htm. Accessed12 October 2007.

9. Overweight and obesity prevalence among Indian women by place of residence and socio-economic status: Contrasting patterns from 'underweight states' and 'overweight states' of India. Soc Sci med. 2015 Aug;138:161-9.

10. Principles for estimation of energy requirements. Available at: http://www.fao.org/docrep/003/AA040E/AA040E04. htm. Accessed Jan $15^{\text {th }} 2016$.
11. The American association of clinical endocrinologists and the American college of endocrinology, advanced framework for a new diagnosis of obesity as a chronic disease; 2014.

12. Sturm R. Increase in morbid obesity in the USA 20002005. Public health. July 2007;121(7);492-6.

13. Bei-Fan Z. Predictive values of body mass index and waist circumference for risk factors of certain related diseases in Chinese adults: study on optimal cut off points of BMI and WC in Chinese adults. Asia Pac j clin Nutr. Dec 2002;11(8):685-93.

14. De Lorenzo A, Soldati L, Sarlo F, Calvani M, DiLorenzo N, DiLorenzo L. New obesity classification criteria as a tool for bariatric surgery indication. World J Gastroentereol. 2016 Jan 14;22(2):681-703.

15. Garber A, Abrahamson M, Barzilay J, Blonde L, Bloomgarden Z, Bush M, et al. American Association of Clinical Endocrinologists' comprehensive diabetes management algorithm 2013 consensus statement. Endocrine Practice. 2013 May 1;19 (Supplement 2):148.

16. Garvey WT. New tools for weight loss therapy enable a more robust medical model for obesity treatment: Rationale for a complication centric approach. Endocrine Practice. 2013;19:864-74.

17. Rohilla R, Rajput M, Rohilla J, Malik M, Garg D, Verma M. Prevalence and correlates of overweight/obesity among adolescents in an urban city of north India. J Family Med Prim Care. 2014 OctDec;3(4):404-8.

18. Deepa M, Farooq S, Deepa R, Manjula D, Mohan V. Prevalence and significance of generalized and central body obesity in an urban Asian Indian population in Chennai, India (CURES:47) Eur J Clin Nutr. 2009;63:259-67.

19. Bhardwaj S, Misra A, Misra R, Goel K, Bhatt SP, rastogi $\mathrm{KV}$, et al. High prevalence of abdominal, intraabdominal and sub cutaneous adiposity and clustering of risk factors among urban Asian Indians in North India. PLoS One. 2011;6:e24362.

20. Shirazi IB, Hamid S, Rafiq M, Hamid S. A crosssectional study to determine sex-wise prevalence of obesity in adults of Kashmiri population. Int $\mathbf{J}$ Res Med Sci. 2014;2;667-71.

21. Muhammad A, Khan A, Khattak MMAK. Prevalence of obesity in male in relation to dietry intake and physical activity level. Pak J Nutr. 2003;2(4):234-7.

22. Khan AA, Khan A. Prevalence and etiology of obesity-An overview. Pak J Nutr. 2004;3(1):14-25.

23. Pradeepa R, Anjana RM, Joshi SR, et al. Prevalence of generalized and abdominal obesity in urban and rural India-the ICMR-INDIAB study (phase 1) [ICMRINDIAB-3]. Indian J Med Rese. 2015;142(2):139-50.

24. Undavalli VK, Ponnaganti SC, Narni H. Prevalence of generalized and abdominal obesity: India's big problem. Int J Community Med Public Health. 2018 Apr;5(4):1311-6.

25. Mumbai: IIPS. International Institute for Population Sciences (IIPS) and Macro international. National 
Family Health Survey (NFHS3), 2005-06: India: 2007; I. Available at: ttps://dhsprogram.com/pubs/pdf/FRIND3/FRIND3vol1andvol2.pdf

26. Pandey RM, Gupta R, Misra A, Misra P, Singh V, Agrawal A, et al. Determinants of urban-rural differences in cardiovascular risk factors in middleaged women in India: a cross-sectional study. Int $\mathbf{J}$ Cardiol. 2013;163:157-62.

27. Al Mahroos F, Al Roomi K. Obesity among adult Bahraini population: impact of physical activity and educational level. Ann Saudi Med. 2001;21(3-4):1837.

28. Serena L, Mien CC, Deurenberg-Yap M. Review on epidemic of Obesity. Ann Acad Med. 2009 Jan;38(1):57-65.

29. Epidemiology and Disease Control Dept., Ministry of Health. National Health survey of Singapore, 1998. In: Epidemiology and Disease Control Dept., Ministry of
Health. Singapur: National Library Board Singapore;1999:108.

30. Health Topics, Obesity World Health Organisation retrieved 14 Dec 2017. WHO obesity Available at: https://www.who.int/health topics/obesity

31. Wilson C, Gilliland S, Moore K, Acton K. The epidemic of extreme obesity among American Indian and Alaska native adults with diabetes. Prev Chronic Dis. 2007 Jan;4(1):A06.

32. Ogden CL, Carroll MD, Kit BK, Flegal KM. Prevalence of childhood and adult obesity in United States, 2011-12. JAMA. 2014 Feb;311(8):806.

Cite this article as: Singh S, Sabharwal RK, Bajaj JK, Samal IR, Sood M. Age and gender based prevalence of obesity in residents of Punjab, India. Int J Basic Clin Pharmacol 2019;8:1038-43. 